Perbandingan kemampuan diagnosa ELISA dan HPLC untuk deteksi toksin ..... (Angela Mariana Lusiastuti)

\title{
PERBANDINGAN KEMAMPUAN DIAGNOSA ELISA DAN HPLC UNTUK DETEKSI TOKSIN DIARRHETIC SHELLFISH POISONING PADA KEKERANGAN
}

\author{
Angela Mariana Lusiastuti*) dan Rosmawaty Peranginangin ${ }^{* *}$ \\ *) Pusat Riset Perikanan Budidaya, Jakarta \\ **) Balai Besar Riset Pengolahan Produk dan Bioteknologi Kelautan dan Perikanan, Jakarta
}

\begin{abstract}
ABSTRAK
Tujuan dari penelitian ini adalah untuk mengetahui kemampuan diagnosa dari ELISA dan HPLC dalam mendeteksi toksin Diarrhetic Shellfish Poisoning pada kekerangan. Asam okadaik dideteksi menggunakan DSP Quick Check Test Kit ELISA sedangkan HPLC menggunakan 2 metode yang berbeda pada proses ekstraksi dan kondisi HPLC yang digunakan. ELISA yang digunakan adalah ELISA kompetitif menggunakan mikroplat 96 lubang, $8 \times 12$ strip yang dilapisi dengan antibodi monoklonal dan antiserum antimouse murni dengan konjugat peroksidase untuk mendeteksi antibodi. Metode HPLC yang digunakan meliputi meto de ekstraksi sampel, proses clean up dan derivatisasi sebelum masuk ke injektor sampel otomatis. Dari hasil penelitian ini diperoleh kesimpulan bahwa ELISA dapat sebagai pilihan untuk monitoring toksin (uji tapis) sedangkan HPLC dapat digunakan untuk mengkonfirmasi sampel positif dalam membantu penegakan diagnosa. HPLC membutuhkan proses clean up dan derivatisasi supaya dapat memberikan hasil yang terbaik.
\end{abstract}

KATA KUNCl: toksin DSP, ELISA, HPLC

\section{PENDAHULUAN}

Kekerangan menjadi vektor fitoplankton dari genus Dinophysis dan Prorocentrum yang mengakumulasi toksin Diarrhetic Shellfish Poisoning (DSP) di dalam tubuhnya karena cara makannya yang bersifat filter feeder (NOAA, 2003; NOAA, 2004).

Toksin DSP yang termasuk dalam polieter ini berbahaya bagi kesehatan masyarakat dan industri perikanan pada umumnya. Diarrhetic Shellfish Poisoning merupakan inhibitor enzim protein serin atau treonin fosfatase tipe 1 (PP1) dan tipe 2A (PP2A) yang sangat kuat. Kedua enzim fosfatase tersebut berperan di dalam proses fosforilasi dan proses seluler di dalam sel, sehingga hambatan pada kedua enzim tersebut akan menyebabkan gangguan metabolisme sel di dalam tubuh manusia yang mengkonsumsinya (Dickey et al., 1990).

Insidensi intoksikasi DSP pertama kali dilaporkan di Belanda dengan gejala diare, mual, muntah, dan sakit perut (Kat, 1979). Dosis asam okadaik yang merupakan komponen utama toksin DSP untuk dapat menimbulkan diare adalah 40--50 $\mu \mathrm{g} /$ orang dewasa. Insidensi DSP di Norwegia, sekitar 70 orang keracunan Blue mussel atau sekitar 54\% terintoksikasi dengan gejala tipikal DSP. Konsentrasi toksin DSP pada waktu itu yang diisolasi dari makanan sisa adalah sekitar 55--65 $\mu \mathrm{g}$ ekuivalen asam okadaik/100 g daging kekerangan (Kat, 1979). Suganuma et al. (1988) meneliti bahwa asam okadaik berperan sebagai promoter timbulnya kanker pada manusia. Hasil eksperimen di laboratorium yang menggunakan tikus yang diberi pakan mengandung asam okadaik dalam jangka waktu lama (chronic feeding) menunjukkan bahwa toksin ini merupakan promotor kanker yang sangat kuat.

Aunoma et al. (1991) juga menyatakan adanya efek mutagenik dan genotoksik dari asam okadaik. Lebih jauh dikatakan bahwa aktivitas promotor tumor, mutagenik, dan genotoksik tersebut erat kaitannya dengan adanya hambatan pada protein fosfatase, sehingga menyebabkan kerusakan DNA (Aunoma et al., 1991).

Toksin DSP (asam okadaik) yang sangat kuat dan berbahaya ini membutuhkan metode yang akurat dan tepat untuk dapat dideteksi keberadaannya pada level yang paling rendah di bawah batas ambang yang diperbolehkan (Maximum Permitted Level, MPL) yaitu untuk DSP 16-$20 \mu \mathrm{g} / 100 \mathrm{~g}$.

Sampai saat ini ada dua jenis metode deteksi toksin yaitu metode analisis dan assai. Metode analisis cenderung mahal dan lebih kompleks dibandingkan dengan metode assai.

Metode analisis mouse bioassay tidak mudah untuk dikerjakan, kurang spesifik dan sensitif. Metode ini 
sekarang sudah mulai ditinggalkan di negara maju karena perhatian terhadap aspek kesejahteraan hewan (animal welfare), bahkan sudah dilarang pada beberapa negara di Eropa.

Untuk mengkaji hal tersebut, maka pendekatan metode deteksi dengan menggunakan Enzyme Linked Immunosorbent Assay (ELISA) dan membandingkannya dengan High Performance Liquid Chromatography (HPLC) perlu diketahui untuk memperoleh metode deteksi yang relatif murah, cepat, tidak memerlukan fasilitas peralatan canggih dan mahal, tetapi berpotensi untuk memperoleh hasil yang akurat. Permasalahan dalam penelitian ini adalah: ingin mengetahui kemampuan diagnosa ELISA dan HPLC dalam mendeteksi toksin DSP pada kekerangan.

Adapun tujuan penelitian ini adalah pengkajian metode deteksi toksin DSP pada kekerangan untuk mengetahui tingkat kemampuan mendiagnosa dari ELISA dan HPLC.

Sedangkan manfaat penelitian ini adalah memberikan informasi tentang kesahihan dan ketepatan ELISA serta HPLC dalam mendeteksi toksin untuk membantu di dalam pengawasan dan pemantauan di area produk hasil laut.

\section{BAHAN DAN METODE}

\section{Bahan}

Penelitian kandungan DSP pada kekerangan dilakukan di perairan Tanjung Balai (Sumatera Utara), Bagan Siapiapi (Riau), Muntok (Bangka), Tanjung Jabung (Jambi) yang dilakukan 3 kali dalam setahun. Penelitian juga dilakukan di Teluk Jakarta sebanyak 2 kali dalam setahun, dan penelitian satu kali setahun dilakukan di Jawa Timur (Sidoarjo dan Pasuruan) serta Gondol (Bali).

Contoh kekerangan dibeli dari nelayan yang menangkap ikan di lokasi penelitian dan dimasukkan kedalam kantong plastik yang telah diberi label dan kemudian disimpan dalam boks yang berisi es untuk dianalisis di laboratorium. Sebelum dianalisis contoh kekerangan dikeringbekukan.

\section{Metode}

1. ELISA

Asam okadaik dideteksi menggunakan DSP Quick Check Test Kit ELISA yang metode ekstraksinya dimodifikasi dan kuantifikasi toksin dioptimalisasi untuk memperoleh limit deteksi yang lebih rendah. Metode ekstraksi Test Kit ELISA: $10 \mathrm{~g}$ kekerangan diblender dengan 5 kali volume metanol $90 \%$ divorteks dan disentrifus kemudian diukur dengan ELISA. Modifikasi metode ekstraksi Test Kit ELISA: $100 \mathrm{mg}$ kekerangan beku ditambah satu $\mathrm{mL} 90 \%$ metanol divorteks dan disentrifus, kemudian ditambahkan akuades 1:1 dan diukur dengan ELISA.

2. HPLCI

Metode ekstraksi: 0,5 g sampel dihaluskan, diekstraksi dengan $40 \mathrm{~mL}$ metanol-air (80:20) dan disentrifus. Cairan dielusi dengan $5 \mathrm{~mL}$ diklorometan. Setelah itu ditambahkan $5 \mathrm{~mL}$ etil asetat dan dimurnikan dengan $0,5 \mathrm{~g}$ silika gel sehingga terbentuk dua fraksi. Fraksi pertama dielusi dengan $10 \mathrm{~mL}$ etil asetat dan fraksi kedua dielusi dengan $15 \mathrm{~mL}$ etil asetat-isopropanol (1:1). Kedua fraksi dicampur dan dievaporasi dengan es nitrogen sampai kering. Residunya dilarutkan dengan 80\%astonitril:air (70:30) dan diukur dengan HPLC.

Kondisi HPLC: kolom C-18, fase mobil: asetonitril:air (70:30), flow rata-rata $1 \mathrm{~mL} /$ menit, lambda $=390 \mathrm{~nm}$, detektor UV, faktor pengencer 10 kali, volume injeksi $10 \mu \mathrm{L}$.

\section{HPLC II}

Metode ekstraksi: sampel diblender dan ditambah 80\% metanol, kemudian disentrifus. Residunya dilarutkan kembali dalam $2 \mathrm{~mL} 80 \%$ metanol. Supernatannya diekstraksi dengan $15 \mathrm{~mL}$ diklorometan dalam heksan, kemudian ditambahkan $5 \mathrm{~mL}$ akuades dan dikeringkan dengan rotary vacuum pada suhu $40^{\circ} \mathrm{C}$.

Proses clean up dilakukan dengan dua cara, menggunakan SPE C-18 dan Myco Sep. Fraksi yang diperoleh dilakukan derivatisasi menggunakan $400 \mu \mathrm{L}$ tetrametil amonium hidroksida dan 9klorometilantracen dalam asetonitril.

Kondisi HPLC: LC high pressure pump (P-580, Dionex P 580 A LPG), automated sample injector (ASI 100), kolom RP-18 (Lichrocart 250-4, Merck), detector photodiode array (PDA-100), fase mobil: 0,1\%trikloro asam asetat dan $10 \%$ asetonitril-akuades, flow ratarata $0,45 \mathrm{~mL} /$ menit, eksitasi $=242 \mathrm{~nm}$, emisi $=450$ $\mathrm{nm}$.

\section{HASIL DAN BAHASAN}

Pada Tabel 1 disajikan hasil deteksi toksin DSP (asam okadaik) menggunakan Test Kit ELISA, modifikasi Test Kit ELISA, HPLCI, dan HPLC II. Hasil tersebut menunjukkan bahwa toksin DSP dari beberapa daerah di Indonesia masih di bawah Maximum Permitted Level.

Konfigurasi DSP-check Quick Test Kit adalah ELISA kompetitif langsung yang dapat digunakan untuk kuantifikasi asam okadaik baik dari ekstrak kekerangan maupun dari sampel plankton segar sebagai sumber toksin. ELISA kompetitif langsung ini menggunakan antibodi monoklonal sebagai antibodi penangkap dan 
Tabel 1. Hasil deteksi toksin DSP (asam okadaik) menggunakan Test Kit ELISA, modifikasi Test Kit ELISA, HPLC I, dan HPLC II pada kekerangan

\begin{tabular}{ccccc}
\hline $\begin{array}{c}\text { Deteksi } \\
\text { asam } \\
\text { okadaik }\end{array}$ & $\begin{array}{c}\text { Test kit } \\
\text { ELISA }\end{array}$ & $\begin{array}{c}\text { Modifikasi } \\
\text { test kit ELISA } \\
(\mu \mathbf{g} / \mathbf{1 0 0} \mathbf{~ g )}\end{array}$ & $\begin{array}{c}\text { HPLC I } \\
(\mathbf{p p b} / \mathbf{1 0 0} \mathbf{g})\end{array}$ & $\begin{array}{c}\text { HPLC II } \\
(\boldsymbol{\mu} \mathbf{g} / \mathbf{1 0 0} \mathbf{g})\end{array}$ \\
\hline 1 & $200 \mathrm{ppb}-2 \mathrm{mg} / \mathrm{L}$ & 0,04 & 9,85 & 0,14 \\
2 & $200 \mathrm{ppb}-2 \mathrm{mg} / \mathrm{L}$ & 0,025 & 15,48 & 0,15 \\
3 & $200 \mathrm{ppb}-2 \mathrm{mg} / \mathrm{L}$ & 0,05 & 12,83 & 0,22 \\
\hline
\end{tabular}

menggunakan 9-klorometilantracene dan tetrametilamonium hidroksida yang menghasilkan asam okadaik sangat stabil dan memberikan gambaran kromatogram yang bersih. Limit deteksi ELISA dan HPLC II tidak jauh berbeda yaitu $0,2 \mu \mathrm{g} / \mathrm{g}$ dan $0,1 \mu \mathrm{g} / \mathrm{g}$. Menurut Van Emon (2001), metode kromatografi dan imunoassai mempunyai persamaan konsep, seperti sifat antibodi yang selektif sama dengan pelapisan pada antibodi anti-mouse murni yang dikopel dengan peroksidase sebagai antibodi detektor (Gambar 1).

DSP-check Quick Test Kit digunakan sebagai uji semikuantitatif yang ditujukan untuk uji tapis toksin asam okadaik dengan kisaran deteksi 10 ppb sampai $>2$ mg/L. Modifikasi yang dilakukan adalah melalui pengenceran larutan standar asam okadaik dengan konsentrasi 2,5; 5; 10; 25; 50; dan $100 \mathrm{ng} / \mathrm{mL}$ sehingga diperoleh kurva standar yang sigmoid. Modifikasi ini ternyata dapat meningkatkan sensitivitas test kit dari jenis tes semi kuantitatif menjadi tes kuantitatif dengan memperoleh batas ambang yang lebih akurat untuk interpretasi hasil ELISA yang diperoleh.

Sebenarnya pemeriksaan menggunakan HPLC bertujuan untuk mengkonfirmasi hasil positif yang diperoleh dari pemeriksaan menggunakan ELISA (NOAA, 2004).

Hasil HPLC I berbeda dengan hasil HPLC II di mana HPLC II memberikan hasil yang lebih kecil dibandingkan HPLC I karena dilakukan proses clean up dan derivatisasi

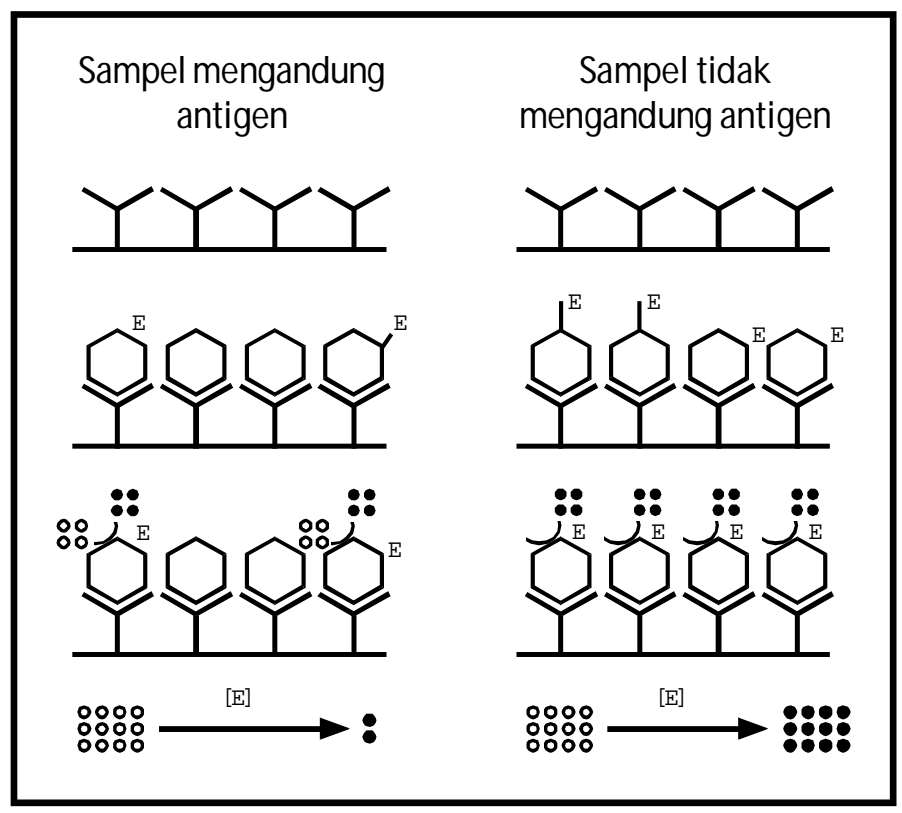

Gambar 1. Konfigurasi ELISA kompetitif langsung kolom. Jika HPLC memerlukan panjang kolom tertentu, maka ELISA dapat juga menggunakan tabung atau lempeng mikrotiter. Kolom HPLC memerlukan suhu tertentu, ELISA pun memerlukan suhu inkubasi pula. Jika HPLC membutuhkan detektor, ELISA juga mempunyai dua jenis detektor yaitu detektor primer (antibodi) dan detektor sekunder (enzim). Perbedaannya adalah imunoassai lebih tepat untuk uji tapis yang membutuhkan waktu cepat dengan kualitas data yang akurat (NOAA, 2003).

Gambar 2 adalah kromatogram toksin asam okadaik yang dihasilkan dari HPLC II.

Perbedaan hasil deteksi pada HPLC I dan HPLC II dapat disebabkan oleh faktor-faktor sebagai berikut: tingginya kandungan lipid pada sampel kekerangan sehingga perlu dilakukan clean up menggunakan SPE C-18 ataupun MycoSep sehingga harus ditentukan terlebih dahulu jumlah ekuivalen jaringan (tissue) yang akan dimasukkan.

Faktor kedua adalah kolom yang digunakan, karena ada kolom yang tidak dapat memisahkan toksin secara efisien. Hal ini sering terjadi pada sampel kekerangan, karena material dalam ekstrak yang terabsorbsi bereaksi dengan packing material dan mengganggu kondisi HPLC. Menurut Hess et al. (2001), loading capacity dari tiap-tiap cartridge berbeda-beda, sehingga diperlukan studi validitas cartridgesebelum dipakai. Ekstrak antar spesies kekerangan juga ada perbedaan, misalnya scallop mengandung lipid konsentrasi tinggi sehingga akan memberikan interferensi yang tinggi pula.

Faktor ketiga, retensi toksin pada kolom dipengaruhi oleh kekuatan ionik fase mobil (fase gerak). Kekuatan ionik yang rendah menyebabkan toksin teretensi, sedangkan kekuatan ionik yang terlalu kuat menyebabkan toksin akan hilang karena terelusi secara cepat. Selain itu, kondisi pH sangat berpengaruh pada fase gerak. Penurunan $\mathrm{pH}$ walau hanya 0,5 unit saja akan mengurangi retensi toksin. Kandungan bahan padat terlarut yang tinggi juga mempengaruhi waktu retensi toksin di dalam kolom. 


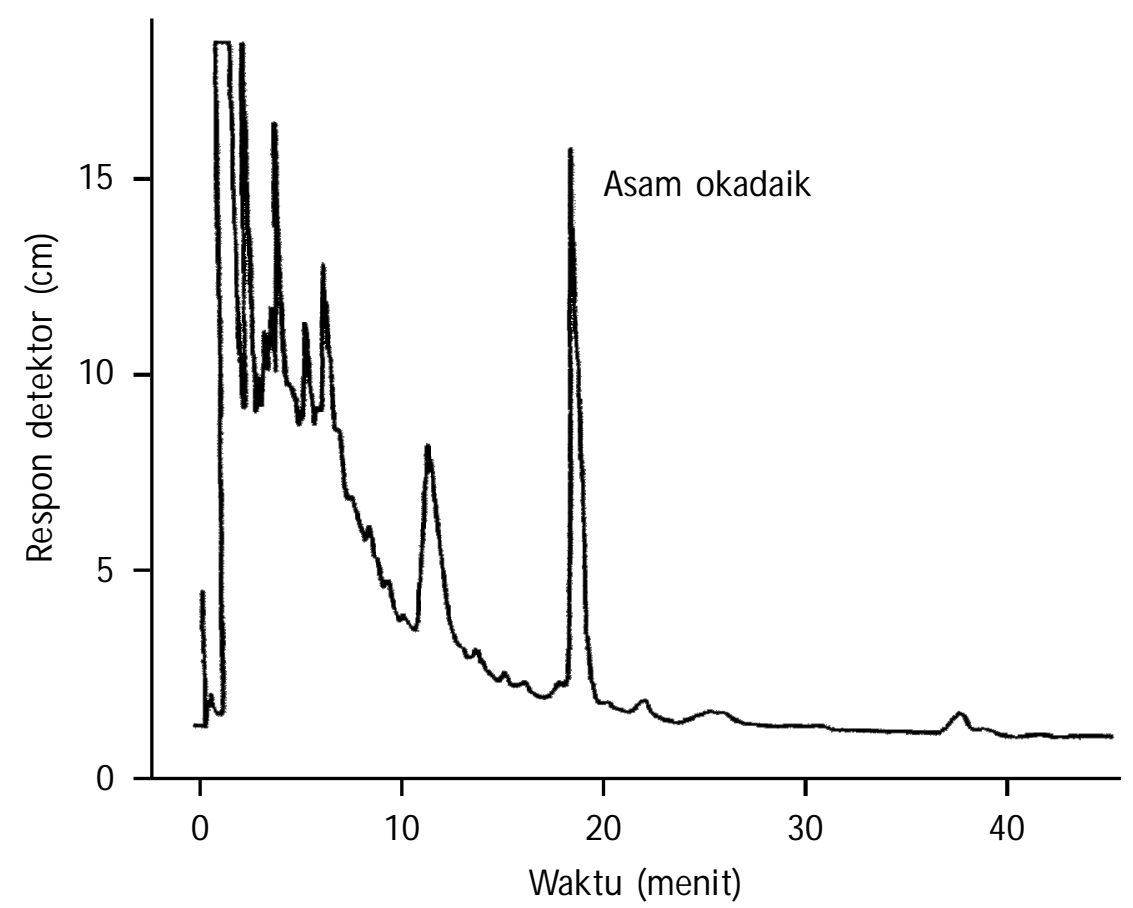

Gambar 2. Asam okadaik pada kekerangan dengan waktu retensi 19 menit

\section{KESIMPULAN DAN SARAN}

1. ELISA dapat menjadi pilihan untuk pemeriksaan uji tapis sampel (tes skrining) sedangkan HPLC dapat digunakan untuk konfirmasi sampel yang positif sebagai penegakan diagnosa.

2. Deteksi toksin DSP pada kekerangan menggunakan HPLC memerlukan proses clean up dan derivatisasi untuk mendeteksi lebih baik dan akurat.

3. Perlu penelitian lebih lanjut untuk mengkaji analisis risiko yang dikaitkan dengan konsumsi produk hasil laut asal Indonesia yang berisi toksin DSP berupa data toksiko kinetik, mekanisme kerja toksin, dan hubungan dosis toksin dengan respon yang ditimbulkan.

\section{DAFTAR PUSTAKA}

Aunoma, S., C. Florio, E. Luxich, S. Sosa, R.D. Loggia, and T. Yasumoto. 1991. Mutation induction by okadaic acid, a protein phosphatase inhibitor in $\mathrm{CHL}$ cells. Mutation Research. 250: 375- 381.

Dickey, R.W., S.C. Bobzin, D.J. Faulkner, F.A. Bencsath, and D. Andrzejewsky. 1990. Identification of okadaic acid from caribbean dinoflagellate, Prorocentrum concavum. Toxicon. 28: 371-376.
Hess, P., S. Gallcher, L.A. Bates, and N. Brown. 2001. Determination and confirmation of the amnesic shellfish poisoning toxin in shellfish from scotland by liquid chromatography and mass spectrometry. J. AOAC. 84: 1,657-1,667.

Kat, M. 1979. The occurence of Prorocentrum species and coincidental gastrointestinal illness of mussel consumers. Dalam Taylor, D. and Seliger, H.H. (Eds.). Toxic Dinoflagellate Blooms. Amsterdam: Elsevier. $265 \mathrm{pp}$.

NOAA. 2003. Marine biotoxin. Magazine Online.htm. October, 30, 2003. p. 5-7.

NOAA. 2004. Blooming Algal Blooms. Magazine Online.htm. July, 30, 2004. p. 8-9.

Suganuma, M., H. Fujiki, H. Suguri, S. Yoshizawa, M. Hirota, M. Nakayasa, M. Oijika, K. Wakamatsu, K. Yamada, and T. Sugimura. 1988. An alternative theory of tissue specificity by tumor promotion of okadaic acid in glandular stomach of rats. Carcinogen. 13: 1,841-1,845.

van Emon, J.M. 2001. Immunochemical applications environmental science. J. AOAC. 84: 125- 133. 